\title{
A RESPONSIBLE AGENDA FOR APPLIED LINGUISTICS: CONFESSIONS OF A PHILOSOPHER
}

\author{
Albert Weideman \\ University of Pretoria
}

\begin{abstract}
When we undertake academic, disciplinary work, we rely on philosophical starting points. Several straightforward illustrations of this can be found in the history of applied linguistics. It is evident from the history of our field that various historically influential approaches to our discipline base themselves upon different academic confessions. This paper examines the effects of basing our applied linguistic work on the idea that applied linguistics is a discipline concerned with design. Such a characterisation does justice to both modernist and postmodernist emphases in applied linguistics. Conceptualisations of applied linguistics that came with the proposals for communicative language teaching (CLT) some thirty to forty years ago propelled the discipline squarely into postmodern times. To account for this, we need to develop a theory of applied linguistics which shows what constitutive and regulative conditions exist for doing applied linguistic designs. A responsible agenda for applied linguistics today has as its first responsibility to free the users of its designs from toil and drudgery, as well as from becoming victims of fashion, ideology or theory. Secondly, it should design solutions to language problems in such a way that the technical imagination of the designer is not restricted but supported by theory and empirical investigation, and that the productive pedagogical fantasy of the implementers of such plans is set free. Thirdly, it must seek to become accountable by designing theoretically and socially defensible solutions to language problems, solutions that relieve some of the suffering, pain, poverty and injustice in our world.
\end{abstract}

\section{Keywords}

Applied linguistics; accountability; modernist and postmodern perspective; theoretical frameworks/foundations; research agenda

\section{THE NATURE OF CONFESSIONS}

The title and subtitle of this paper bring with them a number of implications. The first and most obvious is that it will be concerned with fundamental questions, relating to what I and others have called the foundations of the discipline. Such theoretical foundations are by their nature philosophical, as will become evident from the historical illustrations below. In possessing philosophical foundations, applied linguistics is by no means unique: it is a characteristic that it shares with all other disciplines. The second implication is that, in order to articulate an agenda for a discipline such as applied linguistics, one needs a certain yardstick. I have chosen the term 'responsible' as a measure of that agenda, which of course has the further implication that the discipline may also generate an agenda for the work to be 
done within it that may fall short of certain standards (for this use of the term, cf. Schuurman 2005: 41f.). The third, perhaps less obvious implication, and which therefore needs spelling out, is that in generating an agenda for its work, a discipline needs a broader theoretical framework. My argument, like that of Corder (1972: 3), will be that this framework is once again of a philosophical nature (Weideman 1983, 1987, 1999, 2003, 2006a, 2007b).

The general point $I$ therefore wish to make at the outset is this: it is in the nature of academic confessions that they reveal what has been or what will become the basis for theoretical action. As Widdowson (2005: 13) aptly remarks, with reference to his interpretation of the third tradition of doing applied linguistics that will be discussed in the next section, such beliefs, however erroneous or invalid, may still provide the basis for theoretical work:

The belief in interdisciplinarity as the essential enabling feature of applied linguistics rests, I believe, on rather shaky foundations. But a belief does not have to be valid to be effective as a basis for action...

By articulating a belief about what a discipline should do, academic confessions provide a platform for action and for critical debate. The more comprehensive and robust the articulation is, the better it will be able to account for apparently disparate or even contradictory developments within the history of a discipline.

A related point is a more contextual and in a sense personal one. If it is in the nature of confessions that they reveal what has been or what will become the basis for action, we should also acknowledge that sometimes that articulation is delayed or obscured by other considerations. In my own work, I have always attempted to work within the responsible framework that I shall try to sketch in this paper. While I know that, and how, I have been guided by this framework, I am also aware that I have not always chosen to give it prominence in the articulation of every single design, be it of a test or of a course (e.g. Weideman 2007c). One reason for this is that the articulation of one's fundamental starting points may unnecessarily impede, for others, the usefulness or even the implementation of the designed solution to a language problem. How well I have succeeded in being guided by this framework is not for me to judge; the point I wish to make is that I think it has allowed me to work with integrity, or with what Allwright (2006: 11) calls 'a sense of coherence for my own career in applied linguistics'. Delaying their articulation does not mean that such frameworks should never be profiled and articulated; on the contrary: the current paper seeks specifically to reflect on the importance of doing exactly that. In the work of my fellow applied linguists over the last quarter of a century, both within and outside of the scholarly organisation that we set up here to deal with applied linguistic work, I have noticed, however, a certain impatience or at least a reluctance when it comes to discussing the fundamentals of our discipline, even when we have gathered to discuss ostensibly important ideas such as what constitutes a socially responsible applied linguistics (cf. the contributions and discussion in Weideman 2000). I have thought, at times, that this reluctance may have something to do with the urgency of applied linguistic work, an urgency which can to some extent be explained by the nature of its research agenda that I shall return to below. But it may also be that our engagement with our applied linguistic work absorbs us so completely that we do not take the time to stand back and take stock, or understand fully the disciplinary foundations we stand on.

Such ignorance of what we base our work on, or in which direction we are heading, sets us up, I have argued, either for victimhood (cf. Weideman 2002a, 2003) or for a kind of 
eclecticism that amounts to nothing more than an excuse not to embrace change (Weideman 2001). With it goes a loss of historical sense of what has been done within our discipline, as well as a potential loss of integrity and of wholeness. The detrimental effects on the teaching of applied linguistics as an a-historical phenomenon should be similarly apparent.

It goes without saying that I therefore find an understanding of the history of applied linguistics an essential part of any debate on its foundations. After briefly considering that in the next section, I shall return to the main argument of this paper, which is that, if we conceive of applied linguistics as a discipline concerned with design, such a characterisation does justice to both modernist and post-modernist emphases in the field. To see why this is so, we need to appreciate the turning point in our conceptualisations of applied linguistics that came with the proposals for communicative language teaching (CLT) some thirty to forty years ago. I hope to argue, further, that the characterisation of applied linguistics as a discipline of design enables us to develop a theory of, or foundational framework for, applied linguistics. This theoretical framework, in turn, allows us to articulate a responsible agenda for applied linguistics. The paper will conclude with a number of specific references to the emancipatory, liberating directions of such an agenda.

\section{TWO LESSONS FROM THE HISTORY OF APPLIED LINGUISTICS}

In the history of applied linguistics there have been numerous influential approaches to the discipline. Some recent discussions of these (e.g. Rajagopalan 2004) make more or less the same point as an outline that I have previously employed to good effect to illustrate the defining characteristics of these various approaches. Without discussing the merits of the following categorisation of what I have called the various 'generations' of applied linguistics, I reproduce below the broad analysis that I have found useful (Weideman 2003):

Table 1: Six successive traditions of applied linguistics

\begin{tabular}{lll}
\hline & Model/Tradition & Characterised by \\
\hline (1) & Linguistic/behaviourist & 'scientific' approach \\
(2) & Linguistic 'extended paradigm \\
model' & language is a social phenomenon \\
(3) & Multi-disciplinary model & $\begin{array}{l}\text { attention not only to language, but also to } \\
\text { learning theory and pedagogy }\end{array}$ \\
& & $\begin{array}{l}\text { experimental research into how } \\
\text { languages are learned }\end{array}$ \\
(4) $\quad$ Second language acquisition & knowledge of a new language is \\
(5) & Constructivism & interactively constructed \\
& & $\begin{array}{l}\text { political relations in teaching; } \\
\text { multiplicity of perspectives }\end{array}$ \\
(6) & Postmodernism &
\end{tabular}


Through our engagement with and knowledge of these traditions of doing applied linguistics, we become professionally aware and literate within the discipline. To be unaware of and unreflective about them is to set ourselves up to becoming the victim of one or a combination of styles of doing applied linguistics. To do applied linguistics responsibly is not to drift along uncritically with the latest, most fashionable style of doing it. Worse still, if we do, we may become so captivated ideologically by a certain way of doing applied linguistics - whatever the label says about its being 'scientific' or 'critical' - that we are unable to see any other.

Let me give one example, from a recent analysis that I have made (Weideman 2007a), of where one sub-branch of applied linguistic work, the design of teaching interventions for academic writing, has potentially been detrimentally affected by being unaware of what has happened in applied linguistics as a broad field. Compare the following two recent characterisations of the history of approaches to writing that I have simplified somewhat for the sake of the exposition. The first is adapted from Lillis's diagrammatic representation (2003: 194: her Table 1):

Table 2: Approaches to writing (Lillis 2003)

\begin{tabular}{lll}
\hline & Theory of language & Pedagogy \\
\hline (1) & Language as autonomous system & Skills approach \\
(2) & Language as individual meaning & Creative self-expression \\
(3) & Language as discursive practices & Socialisation into these \\
(4) & Language as genres with features & Explicit teaching of these \\
(5) & Language as ideological practice & Challenging the status quo \\
\hline
\end{tabular}

The second is from Ivanic (2004: 225):

Table 3: Discourses of writing (Ivanic 2004: 225, Figure 2)

\begin{tabular}{lll}
\hline & Discourse (paradigm) & Approach \\
\hline (1) & A skills discourse & Skills approaches \\
(2) & A creativity discourse & Creative self-expression \\
(3) & A process discourse & The process approach \\
(4) & A genre discourse & The genre approach \\
(5) & A social practices discourse & Functional approaches \\
(6) & A sociopolitical discourse & Critical literacy \\
\hline
\end{tabular}

Not only are there strong similarities between these two characterisations of approaches to writing (and for a largely similar one, cf. Johns 2005a), but there also appears to be some alignment with the characterisation of the successive approaches to applied linguistics in Table 1 above. It is instructive, however, to note the differences between Tables 2 and 3, on 
the one hand, and Table 1, on the other. These would indicate a number of potential causes for concern: 1) in spite of the recent ascendancy of critical, postmodern approaches to writing, these various kinds of designs for writing interventions may still be influenced by a notion that applied linguistics relies solely on linguistics, or at least on a rich (social) notion of language, that was characteristic of second generation applied linguistics; 2) these approaches to writing may not have benefited from the more empirically inclined fourth and fifth generation work in applied linguistics, second language acquisition research and constructivism, that have investigated, from different perspectives, how language is acquired. Only those more familiar with approaches to writing will be able to tell whether these concerns are real or not, but the two characterisations given by writing experts themselves of this seem to indicate that not enough work may have been done to investigate the actual acquisition of writing. This may be due to an anti-assessment or anti-empirical bias in the currently dominant critical, postmodern paradigm. Nonetheless, I believe these issues deserve consideration. The main point, however, is that in some way, the design of the teaching of writing may have become isolated from applied linguistic work. When I ask writing experts about this, they agree that this is the case (Johns 2005b, personal communication). A variety of institutional and organisational reasons may be advanced for this - in the USA, for example, there is a strong, institutionalised tradition in the teaching of 'composition.' Given the current dominance of an approach to writing that considers political issues as the most important ones in the design of writing interventions, it is interesting nonetheless that no-one has picked up on the reification of certain approaches within institutions, and their patently political effects.

This unfortunate separation of the ways between approaches to writing and applied linguistics is also evident in the contents of two new recent handbooks on applied linguistics. By far the more authoritative of the two, the Handbook of applied linguistics (Davies \& Elder 2004) does not contain a single chapter with a title that refers to writing. By contrast, the one that derives from the USA (Kaplan 2002) has a substantial chapter on second language writing (Leki 2002), but nothing on the critical turn in applied linguistics in its postmodern incarnation (cf. Kumaravadivelu 2006, who is highly critical of the self-congratulatory way in which the compilers of the Kaplan [2002] handbook go about omitting some of the most prominent topics and themes within applied linguistics today). For an historically earlier example of the treatment of writing in an applied linguistics handbook, see the piece on 'Reading and writing' by Davies and Widdowson (1974: 155-201) in the third volume of The Edinburgh course in applied linguistics (Allen \& Corder 1974).

The final point about the characterisation of the history of applied linguistics (as in Table 1, above) that I wish to make here has already been noted indirectly above, but needs to be highlighted again: these six different styles of doing applied linguistics fall into two broad categories: modernist approaches (the first five) and postmodern ones (the sixth, sometimes in combination with the first five). In the next section, after reviewing first several modernist definitions of applied linguistics (exhibits 1-4), and then some postmodern, critical ones (exhibits 6-7; 9-12), we consider an alternative vision for applied linguistics: a theoretical starting point that may make it possible to see the commonality between the modernist and postmodernist ways of doing applied linguistics. 


\section{TWO WAYS OF LOOKING AT APPLIED LINGUISTICS, AND A TWIST IN THE TALE}

The idea of applied linguistics as a discipline of design goes back to two different influences: a largely neglected definition of the field first mooted by Pit Corder (1972), and an insight of Egbert Schuurman (1972; also1977). I shall return below to the Corder definition, but start with Schuurman's (1972: 377-378) observation that one of the less desirable effects of the notion of 'applying science' is that theory is conceived as being both authoritative and comprehensive, so that, if it prescribes a design, as was evident in the work of first generation applied linguists, that design would by virtue of being 'scientific' be the most efficient. In order for the design to be credible, such a conception posits that there is continuity between the theory and its application in the design. No wonder then, that within first generation applied linguistics, such definitions of the field as the following were advanced:

(1) It would ... make ... sense to regard applied linguistics as just that part of linguistics which, in given situations, turns out to have applications in some other field (Buckingham \& Eskey 1980: 3).

(2) I would posit that applied linguistics constitutes the point at which all study of language comes together and becomes actualized (Kaplan 1980a: 10).

Applied linguistics is viewed here as nothing more than part of linguistics, although at the time of its conception it was conceived at least as a 'new branch ... of linguistics' by Malmberg (1967: 1 [my emphasis]; cf. too Kaplan 1980b). No wonder, too, that such definitions breed scientific hubris, or at least a belief in the ability of scientific analysis to solve and fix all problems. Compare the next two exhibits, from Wilkins (1975: 208; 228), as instances of how the idea of continuity between science and the designed solutions for language teaching becomes a prerequisite for progress:

(3) By studying language in as scientific a manner as possible we should be able to make change in language teaching a matter of cumulative improvement.

(4) We refer to linguistics in an attempt to make the process of change in language teaching less subject to fashion and more dependent on the cumulative increase in our knowledge of language learning and teaching.

As Schuurman (1972: 378) points out, such conceptions of applying science restrict human creativity, and work against the disclosure of the true meaning of technology by prescribing strict, 'scientifically' sanctioned solutions. The postmodern critique of this kind of applied linguistics (e.g. in Pennycook 1999, 2000, 2004; but also Allwright 2006) is therefore certainly not unreasonable. Allwright (2006: 11) speaks of a movement in applied linguistics from 'prescription' to 'understanding' as one of the six promising directions that the field is taking. As one of Schuurman's own mentors, Van Riessen (1949: 625) had pointed out more than 50 years ago, the design process needs to happen in a space where the technical fantasy and imagination of the designer are not restricted, but enhanced by theoretical analysis: each provides a spark, as it were, for the design process to play itself out contrapuntally ('Het ontwerpen voltrek zicht zodoende in een wisselspel van theoretische bewerking en techniese fantasie'). Corder (1972: 5) is also quite emphatic on this point: to be a good applied linguist one must, in addition to theoretical knowledge, possess 'both imagination and a sharp critical faculty.' 
What is more, such modernist conceptions of applied linguistics as in exhibits (1) to (4) above confuse two irreducible dimensions of our experience: they conflate the theoretical mode, which is concerned with analysis and rationality, and the technical side of reality, which is characterised by a freedom to give form to human action according to an intentional design. The effect of this conflation is that the technical is downplayed, and the theoretical absolutised. The irony is that 'applied science' in reality is often nothing more than the post hoc justification of a technical design, as in audiolingualism. If this is the case, then we should of course seriously question whether applied linguistics is, or has ever been, the application of linguistics.

What alternative does the postmodernist position present? Before one can answer that in an historically appropriate way, one should perhaps first consider a number of developments that constitute the forerunners of postmodernism in language teaching. In a very early analysis that I did a good twenty years ago (Weideman 1987), I argued that the influence of applied linguistics on the field of language teaching - still one of the dominant sub-fields of our discipline - could go into one of two directions: a technicist or a revolutionary one. Of the first of these, attempts in mainstream communicative language teaching (CLT) that sought to have language teaching informed by technical-scientific analyses both of learners' needs and of syllabus and course design, as in the work of Munby (1978), provide evidence. There is an attempt here to give this particular (British) interpretation of CLT some scientific support and refinement, at least in linguistic terms (cf. also Wilkins 1976). The second, so called humanistic direction (cf. Roberts 1982, Weideman 1985, 1986), probably best represented in early CLT by Jakobovits and Gordon (1974), takes the revolutionary (but, interestingly, not yet political) road. 'Humanistic' CLT seeks to achieve the goal of authentic communication in the classroom without first attempting to justify the actual language content of the course in a scientific or quasi-scientific way. Instead, Jakobovits and Gordon - quite some time before Krashen - propose a hypothesis of 'natural growth' for the language learning process (1974: 44f.). Their central theme is freedom, 'the new consciousness of the youth generation, of freedom, of self', and the 'freedom-giving leap into the unknown' (1974: 84), which will bring about changes in the way that language teaching is designed and conducted. Though they claim that they are not propagating revolution, at least not as a political tactic, Jakobovits and Gordon (1974: 97) acknowledge that, to those of the 'older' consciousness, who are used to traditional language teaching, their own account of liberated language instruction 'must evoke a feeling of horror ... Visions of anarchy, chaos, abuse, waste, present themselves...' I commented (Weideman 1987: 154) earlier:

The revolutionary tack is not so much one of political action, but lies in their ideological subscription to the 'unfulfilled promises' of freedom in the future ... What is revolutionary here, in other words, is the vision: a commitment to a future state of liberated happiness, accompanied inevitably by the tunnel vision that is characteristic of all ideologies. The ideal of freedom that asserts itself in humanistic teaching ... has always been the very antithesis of the ideal of science. In this case, too, it embodies an assertion of the freedom of the individual from its bondage by scientific designs. (emphases in the original)

While it should be obvious how these beliefs foreshadow critical, postmodern applied linguistics, there is a second, perhaps even more important element present, this time in mainstream CLT itself, that carried in it the seeds of destruction of modernist approaches to applied linguistics. And this is the twist in the tale, simply put: even mainstream CLT was 
justified theoretically after the fact, i.e. after its designed solutions for language teaching had already gained credence and acceptability.

To claim that mainstream CLT springs from the theoretical ideas of Hymes (1971) or Halliday (1978) is to misrepresent the historical process out of which CLT arose, and to posit a continuity between theory and practice, and even initially between theory and design, that is not there. Indeed, the writings of Hymes and others may eventually have provided some theoretical justification for the design of language teaching in CLT from a sociolinguistic point of view, but this came after the prototype designs and their implementation in practice were already in place. As Paulston, even while emphasising (1974: 350) the importance of Hymes's ideas for the design of language teaching, pointed out at the time, these ideas were preceded, in the five years before her comments, i.e. at least since 1969, but probably earlier, given the time lag between when comments are made and published, by 'an increasing — and justified - concern for communicative activities in language teaching' (Paulston 1974: 348). This is also why Hymes (1985: 15) himself remarked later that his use of the term communicative competence not only came simultaneously with its use by others, but tellingly- that it 'seems to have been introduced independently in the study of teaching and learning'. Indeed, there are examples, such as the language teaching experiment at the Defense Language Institute in California that Carroll (1965: 211) describes, that must surely be the forerunner of what became known in CLT and one of its later interpretations, the Natural Approach (Krashen \& Terrell 1983, Terrell 1985), as the Total Physical Response (TPR) technique. Similarly, Newmark (1966: 161), a good deal before Hymes, was already in the mid 1960s discussing the contrast between learning linguistically identified grammatical structures and the real 'capability a person needs in order to use the language'. Even the article, in 1965, by Prator, which can be regarded as one of the earliest pleas for the introduction of communicative activities in the classroom, has very little of substance to say either about the theoretical justification of these or the content through which such activities can be conducted. And these various examples of the initial lack of continuity between sociolinguistic theory and the design of language teaching concern only one side of the undertaking: the linguistic justification of CLT. Its psychological justification, in the form of fourth generation, or second language acquisition research (Larsen-Freeman 1993; Lightbown \& Spada 1993), and fifth generation applied linguistic work, that took its cue from constructivism (Greyling 1993, Macdonald 1988; Macdonald \& Burroughs 1991; Moulton 1994: 33), arrived much later, specifically in the sustained research by Pica, her associates and others about how understanding and learning come about during the negotiation of meaning across an information gap (Pica \& Doughty 1985; Varonis \& Gass 1985; Doughty \& Pica 1986; Porter 1986; Pica, Young \& Doughty 1987; Pica 1987; Pica, Holliday, Lewis \& Morgenthaler 1989; Pica, Kanagy \& Falodun 1993; Pica 1994; Walz 1996; Pica 1996; Foster 1998; Oliver 2000; for another summary and review of numerous other studies, cf. Nunan 1991).

Once more, the theoretical justification from the psychological angle, like the linguistic defence of CLT, is a belated one: historically, there was no continuity between, in this case, learning theory, and the designs for communicative teaching. At the same time, and for the sake of treating a serious approach to applied linguistic work with the respect it deserves, I take issue with a recent pronouncement by Spolsky (2005: 28f.), claiming that second language acquisition research derives merely from a

... misguided ... approach (that) involved accepting Chomsky's attack on

Skinner as weakening all claims for grammar learning, and adopted Chomsky's 
use of the term 'acquisition' and his search for universal innate grammars in order to condemn all effort to teach languages, glorifying automatic acquisition through exposure to the next needed form ... This had major effects on the profession, justifying the building of a new sub-field to study 'second language acquisition'...

This is a misrepresentation of the importance of fourth generation applied linguistics. Spolsky (2005: 28) of course offers a predictable solution for those, like him, who believe that 'second language acquisition was somewhat limited in parenthood' - they are referred to the notion of educational linguistics that he had introduced. As Larsen-Freeman pointed out in her keynote address to AILA in 1993 (1993, also 1986, Lightbown \& Spada 1993: 72), a number of directions within CLT eventually found some justification in second language acquisition research. That this justification came about after the fact is merely an indication that the continuity with and reliance upon theory had been broken. In the 1970's, as Klosek (1985: 15) has pointed out:

(5) Linguistic theory ceased being applied directly and hypotheses based on other considerations were formulated and tested... Today, the most interesting questions, hypotheses, and theories are from those that have sprung from work already done within the discipline.

The conclusion seems to me to be inevitable: in CLT, the design of language teaching began to precede theory and theoretical justification. One must ask whether the lack of adoption of CLT globally, despite the confessions by teachers that this is the approach that they wholeheartedly support and employ (Karavas-Doukas 1996; Weideman 2002b; Weideman, Tesfamariam \& Shaalukeni 2003), does not perhaps have something to do with this. With this break, however, we land squarely on the doorstep of postmodern times and styles of doing applied linguistics. And it is my further conclusion that, probably because it has been so much reviled, we have generally tended to underestimate the historical contribution that CLT has made to arriving at this point.

Let us therefore now consider how the emerging paradigm that is evident in CLT is echoed in current postmodern conceptions of applied linguistics by looking at a two further exhibits (for the interchangeable use of the terms 'postmodern' and 'critical', as well as the umbrella term 'modernist', see Weideman 2007b). Contrary to my conclusion in the previous paragraph, the definitions that are given below as exhibits (6) and (7) seem to suggest an historical discontinuity with what went before:

(6) Rather than viewing critical applied linguistics as a new form of interdisciplinary knowledge, I prefer to view it as a form of anti-disciplinary knowledge. (Pennycook 2004: 801)

(7) Critical applied linguistics is not about developing a set of skills that will make the doing of applied linguistics more rigorous, more objective, but about making applied linguistics more politically accountable. (Pennycook 2004: 798)

Though they would by no means find universal acceptance, with these definitions applied linguistics has arrived at what ostensibly is a position that is wholly different from what has gone before. The historical analysis I have offered above, however, seems to indicate that there are more links between postmodernism and modernism than at first meets the eye. 
Consider, first, the appreciation that postmodernism brings for a multiplicity of perspectives, or just for variety and idiosyncrasy as such (Allwright 2006: 13). A good example of the postmodern appreciation of the value of multiple perspectives is that of the New London Group (2000: 15), in that there will, for example, 'be a cognitive benefit to all children in a pedagogy of linguistic and cultural pluralism'. Pennycook (2000: 102) is highly critical of this, since his 'sense of the social and cultural ... is not the liberal dream of equitable social relations and celebratory multiculturalism'. Yet surely the sense of plurality that we find in postmodernism was foreshadowed in the multi-disciplinarity attempted by third generation applied linguistics? The remarks by Rampton (1997: 16), in introducing a review of applied linguistics at the end of the previous decade, echo these sentiments:

... what does stand out in ... the state of play in AL [applied linguistics] ... is the level of enthusiasm ... for the challenges ahead... It is difficult to say whether this forward orientation reflects the end of a phase of fragmentation and the resurgence of a spirit of cross-disciplinary interchange ...

Second, consider how the various critical and postmodern approaches to the teaching of writing that were cursorily surveyed in the second section above hark back to the emphasis placed by second generation applied linguistics on an extended, socially enriched, discourse specific notion of language (for a more complete exposition and argument, cf. Weideman 2007a). If we look at the way in which both the 'humanistic' tendency within CLT and mainstream CLT variously contributed to the advent of postmodern, critical approaches, we have a third strand of historical continuity.

This is not to deny that there are indeed differences between modernist and postmodern conceptions of applied linguistics. For one thing, they certainly derive from different belief systems or frameworks. But they are not so different as to constitute a complete, revolutionary break, as some of the rhetoric implies. There are genuinely new insights in critical applied linguistics that have benefited and will continue to benefit the discipline. Note, for example, the appreciation in postmodern approaches for the professional integrity of the teacher, and how that must be respected not only in the way that we conceive of research (cf. again Allwright 2006: 15; also Tarone 2005: 173), but also by those responsible for designing applied linguistic objects. In fact, one of the major advances of postmodernism in applied linguistics has been the high regard not only for the differentiation of the roles of designer and implementer of applied linguistic designs, but also for the professional competence of teachers both as designers in their own right, and as implementers. Unlike in times past when modernist conceptions held sway, and when, as a result of these conceptions, the teacher, as implementer of applied linguistic designs, was at the mercy of the expert designer, the postmodern approach generally sees teachers themselves 'as designers of learning processes and environments' (New London Group 2000: 19).

In these remarks, it is already evident that in postmodernism, as in modernist approaches, the element of the design of language teaching has again gained some prominence. In the next section, I discuss what beneficial effects this may have for how we see applied linguistics.

\section{A THIRD WAY OF LOOKING AT APPLIED LINGUISTICS}

I would like to begin this section with another exhibit (8), the neglected definition of applied linguistics offered by Pit Corder (1972: 6f.) that I referred to at the beginning of the previous section: 
(8) Research in applied linguistics has as its function the finding of solutions to problems which arise in the process of planning or designing ... practical activities ... [A]pplied linguistics, as other applied sciences, is fundamentally concerned with design ...

Some would immediately respond that this definition is modernist to the core. In the context that Corder (1972) made it, I think that would probably be a fair interpretation. But there is more to it than that. Too often, when the idea of 'design' is introduced - especially when one does so in conjunction with the term 'technical' - this is immediately interpreted as having a 'technicist' orientation, or as a renewed call for technicism. Once we state that applied linguistics is a discipline of design, an immediate misunderstanding may therefore arise, which is that it is a field in which language problems are tackled by means of scientifically prescribed, and therefore universally valid solutions. The first bit (language problems are addressed) is correct. As the interpretation of postmodernist applied linguistics of the idea of design that I shall discuss below indicates, the second part (that generally valid solutions can be prescribed by scientific analysis) is not.

The idea of design has indeed been renewed in postmodern applied linguistics. Consider another exhibit, a remark made by Bell (2003: 333) in the context of a discussion and review, amongst others, of the work of Kumaravadivelu:

(9) ... postmethod strategies and principles can be understood as articulating the design features ... of the current paradigm of CLT. What is so refreshing about these design features is that they contain within them the tools - learner autonomy, context sensitivity, teacher/student reflection - to construct and deconstruct the method that inevitably emerges from the procedures derived from them.

Similarly, in the work that Lillis (2003) has done on writing, while working fully in a postmodern and in certain respects a postcritical framework, she notes that too little attention has been paid in this kind of work to a 'design space' (2003: 193). Lillis desires an academic literacies approach to student writing at university - the problem that in this case needs to be understood and addressed - to be developed as a 'design frame' specifically when writing instruction is being planned. She remarks (Lillis 2003: 195):

(10) I am using 'design' here in the broad sense of the application of research understandings to pedagogy... [T] his broad sense of design connects with Kress's particular notion of design in relation to critique ... The point that I want to make here is simply that, to date, little explicit attention has been paid to exploring how an academic literacies stance might inform the theory and practice of student writing pedagogy.

One may observe that Corder's use of the term 'design' is indeed different from its use in postmodern orientations. In the latter, it is often connected, as in the work of Kress (2000), with language and the use of semiotic resources. Yet there is, as is evident from exhibit (10) above, enough commonality with modernist understandings: cf. the phrase: 'in the broad sense of the application of research understandings to pedagogy'. In a similar vein, Janks (2000: 177) comes close to the earlier notions of Corder and Van Riessen (1949) about creativity in design, referred to above, when she notes that the postmodern conceptualisation of 
(11) [design] encompasses the idea of productive power ... (and) recognises the importance of human creativity.

Design is also a significant concept in the contributions to the work of the New London Group on multiliteracies that was published under the editorship of Cope and Kalantzis (2000). Cope and Kalantzis (2000a: 7) remark, for instance, that this idea is central to understanding the work of the New London Group: 'The key concept we developed ... is that of Design, in which we are both inheritors of patterns and conventions of meaning, while at the same time active designers of meaning.'

I was challenged by a reviewer of an earlier analysis on the nature of applied linguistic work (Weideman 2007b) to declare what exactly it means, for applied linguistics, if one views it as a discipline of design. What impact does such a view have on actual work in the field? In order to see what that impact is, I would, however, first need to add a final thread to the argument.

This is that, in the design process, there appear to be several successive phases (Schuurman 1972: 404). When we apply our knowledge of what happens in the process of designing to a consideration of the specific task of designing an applied linguistic artefact such as a language course or a test of language ability, we find the following phases in the process: 1) the language problem is identified; 2) the designer brings together both his or her technical imagination and theoretical knowledge that potentially has a bearing on the problem; 3 ) there is an initial formulation of an imaginative solution to the problem; and, finally, 4) a theoretical justification is sought for the solution designed. There may be some recursiveness in this process, of course, so that the problem itself may be subjected or even re-subjected to analysis (or 'understood' - but now in a more than merely theoretical sense - as Allwright proposes [2006: 13]), or the solution may be modified to align it more closely with its theoretical justification.

When the design has been articulated, it is implemented by competent professionals, such as language teachers or testing administrators or language policy makers and planners, depending on the nature of the sub-field of applied linguistics for which the design has been made. And in the implementation, there is always a relationship between the resources that are used to make the design work in practice, and the ends or purposes to which the successful implementation of the design will contribute. In any design process and its implementation, we thus find a relationship between technical means and ends.

The differences that we see between modernist and postmodern conceptualisations of the idea of applied linguistics as a discipline of design relate, I think, to the different emphases that they place in the relationship between technical means and ends. Modernist or technicist approaches appear to overemphasise the technical means by which a solution to the language problem is designed, so to such approaches it is all important to employ a scientific or technical-scientific analysis. Postmodern approaches or approaches that are socially or politically sensitive place a higher premium on the ends of the plans that are made, so they enquire about how power relationships are affected by implementation of the design. But in both approaches plans are made, and plans are, in a philosophical framework, the expression or articulation of designs. 


\section{AN EMERGING THEORETICAL FRAMEWORK FOR APPLIED LINGUISTICS}

In this final section of this paper, I shall attempt to flesh out a theory of applied linguistics as it is emerging from the various analyses I have made (especially Weideman 1987, 2006a, $2006 \mathrm{~b}$ and 2007b).

Much has been said above regarding the technical mode of our experience, and the theoretical. Specifically, the misconception of their relationship in applied linguistics in modernist conceptions of the field has been discussed. Instead of subsuming the technical sphere of design within the theoretical, as modernist approaches do, an alternative framework for applied linguistics should acknowledge that each of these constitutes a distinct mode of doing things. Indeed, there is in applied linguistics a close relationship between the two, as is evident from the graphic illustration of this in Figure 1.

In this illustration, the leading or qualifying function of an applied linguistic design is to be found in the technical mode of experience, and its foundational function in the theoretical or analytical mode. The interplay between these two functions is critical for the design that will emerge, and has been described above in the four phases that characterise the design process.

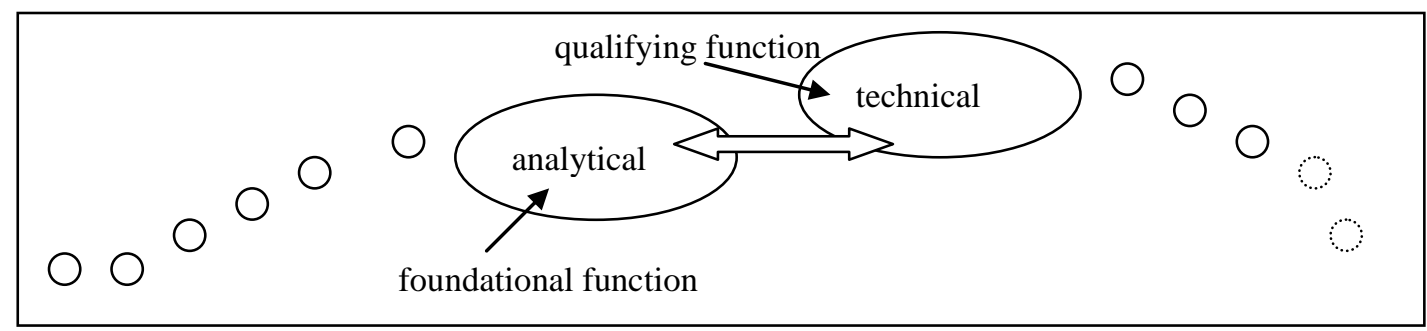

Figure 1: Leading and foundational functions of applied linguistic designs

It is important, however, to note that in terms of this framework the theoretical does not precede the technical. On the contrary: the leading function is that of the technical design. When one turns this otherwise reciprocal relationship on its head, and gives priority to the theoretical, the history of our field, as I hope I have adequately demonstrated above, warns us that there will be justified opposition. Equally, as the design process described above also makes clear, there is a reciprocity between designing and theoretical analysis. If applied linguistics is to be an academic discipline, there is a need, at least, for the theoretical justification of the design, even though that may not have precedence over the design.

The rationale or theoretical justification of the design is therefore not the leading or qualifying function of the design, but still its very important founding function. Before CLT had this rationale, its claims were therefore, as we have seen above, significantly weaker. As another example, consider the notion of the content validity of a language test. In contrast to its face validity, which is the judgement that lay people may make of what the test does and how well it will probably do it, content validity entails a judgement - normally systematically made and recorded - of experts on how representative and adequate the test is measuring what it sets out to measure (Alderson, Clapham \& Wall 1995: 173f.; Messick 1988: 38). Such judgement, to the extent that it is based upon a technical analysis (normally of the specifications of the test), supports the theoretical rationale or foundation of the measuring instrument. But we should note again that this analysis can only be done after there is at least a prototype test design available to make such judgement on. In short, the analytical foundation of an applied 
linguistic design remains important, though not in the sense that it guides or prescribes the design.

Instead of scientifically prescribed solutions, in which technical-scientific analyses have priority, applied linguistics as a discipline has advanced to the point where it acknowledges that there are, for the design of language testing or language teaching, as well as, of course, for other fields with which the discipline is concerned (for an exposition, cf. Davies 1999), certain design principles. Each of the connections that the technical sphere has with other dimensions of our experience yields one or more design principles. This is the meaning of Kumaravadivelu's (2003) reinterpretation of CLT and other current and former approaches to language teaching in his book Beyond methods, and what he calls 'macrostrategies'. This is also the implication of the current postmodern view of the teacher as both designer and implementer. If, as in any other design disciplines, applied linguistic plans are justified in terms of certain principles, then those implementing the plans in principle have access and recourse to the same design principles that everyone else has: they need not be a mystery, justifiable theoretically only in a cloud of scientific jargon. On the basis of these principles, other interpretations of the original design can be made, and different implementations achieved. That other interpretations are possible of designs for language teaching, for example, have long been known. Tesfamariam (2000) and Shaalukeni (2000) have shown, for example, that there is no such thing as a 'teacher-proof' curriculum or even textbook. In fact: there cannot be, and there should not be. The original interpretation of the initial design is not sacrosanct. It can be challenged. To make it sacrosanct is to deny the professional competence of the implementing agent, such as the language teacher.

In that sense at least - that we should proceed from design principles - the modernists of first generation applied linguistics were correct (cf. Lado 1964). The trouble was that their principles were, upon examination, not scientific at all (Weideman 1987: 41-42; Lamendella 1979) and contradicted with rigid prescription the freedom and agency they implied.

To see how the connections that arise from the relationship of the technical sphere, which qualifies applied linguistic designs, with other modes of experience yield design principles, we may examine a number of examples: the concept of test reliability, for instance, derives from the connection between the technical sphere and the kinematic mode, which is characterised by regular movement. This connection analogically yields a principle or requirement for that particular applied linguistic design to have technical consistency. The various notions of test validity generally refer to the requirement for a test to do what it should, which relates to the power or effect of a test as a technical instrument, or the connection between the technical and the physical side of reality, the sphere of energy-effect. All these connections lie in what is called the foundational direction, and are therefore constitutive or founding concepts in applied linguistics. To summarise once again with a graphic illustration (please see next page): 


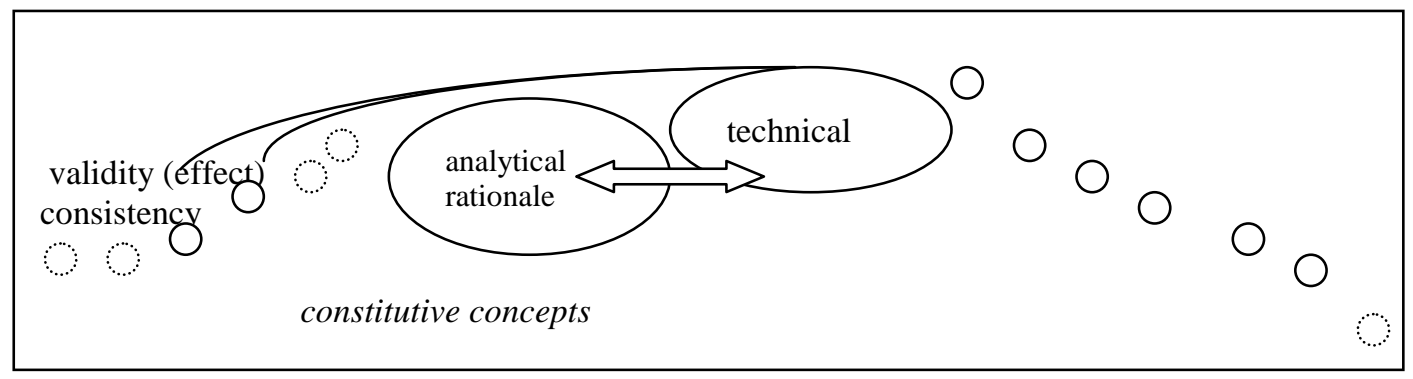

Figure 2: Constitutive concepts in applied linguistics

At the same time, the technical sphere anticipates those other dimensions of experience that lie in the other direction, yielding now not only constitutive principles like technical consistency and effect, but regulative conditions for applied linguistic designs. So in the way that the technical side of reality connects with the lingual or symbolic mode of experience, that connection yields the regulative requirement that a design should be articulated and expressed, usually in the form of a plan. In the case of a language test, this plan is embodied in the test construct and the specifications that flow from this. In the case of a language course, the plan normally takes on the form of a curriculum.

In anticipating the implementation of an applied linguistic product, its leading technical function connects with the social. Designs anticipate their implementation within some social context: they are interactively implemented by human agents who for the most part have distinguishable social roles. In language teaching, these may be policy makers, curriculum and materials designers, managers and administrators, teachers, students and others, and postmodern perspectives have alerted us to how these roles can change and be exchanged. Postmodernism has also allowed us to see that each new implementation of a design is unique, and different from any prior or subsequent employment thereof.

Without implementation in a specific social context, the disclosure of the meaning of the technical cannot be achieved. Such disclosure is evident, further, in the connection between the technical and the economic dimensions of life, and yields the regulative principle of the technical utility of the design. The utility of a test, for example, requires that it be designed so that the most frugal solution is implemented.

A further design principle is that the technical product must also be aligned or brought into harmony with the many, potentially conflicting logistical and administrative demands upon it. In this principle, the leading technical function of an applied linguistic design anticipates its disclosure by the aesthetic dimension of our experience. Let me give an example of where a conflict may arise between the technical fantasy and imagination of the designer of an applied linguistic object and logistical constraints. In making a test, test developers often make use of item banks. These are technical tools, normally in the form of a database, in which pre-tested items can be stored and recalled for later use. But say now that the test construct is so rich and imaginative, while simultaneously being theoretically justifiable in terms of its construct, that the item bank is unable to handle the kind of test design that is called for. The tool is in this instance too limited to deliver the support required for the new design. In such a case, there is a clear misalignment or disharmony between logistical possibility and technical imagination, and it is to the latter that precedence must be given. The tool must therefore first be redeveloped, or changed to handle what it should. 
In weighing up the various considerations for the best design, the technical dimension anticipates the juridical mode of experience. And in this connection, postmodern perspectives in applied linguistics have probably contributed most. So, for example, we accept now that our designs must be accountable, open for scrutiny not only by experts, but by the users and even by the public. We can no longer defend our designs only with reference to other expert opinion. The technical defensibility of a design, which links the technical and juridical, depends no longer only on its theoretical defensibility. I agree with Bygate's (2004) contention that 'applied linguists need to be doubly accountable', i.e. both to their peers and to the lay communities they serve. That is why the link between 'standards' for language testing and public accountability is not always as productive as is conventionally thought. What applied linguistics needs is a public defensibility of its designs, and this can best be achieved by beginning with the notion of transparency. The clearer we can articulate the purposes of the design for a larger public, and so achieve greater technical transparency, the easier it will be not only for others to access our designs and scrutinise them, but also for us to respond with integrity and honesty to public criticisms of them.

The regulative condition of public defensibility that should attach to applied linguistic designs has also enlivened and disclosed further our notions of validity. The call, for example, for examining not only certain (constitutive, in this analysis) concepts of test validity, such as construct (theoretical) or content (effect) validity, but also what Messick (1988: 33; cf. also 39f., 42) has called 'the functional worth of scores in terms of social consequences of their use', or test impact, has disclosed another regulative condition for test design.

In short, a further regulative condition for applied linguistic designs is that they should be used not to disadvantage others, but to care for them. Our designs, as technical objects, anticipate the love we have for others. In foundational terms: the technical design already in its design anticipates its ethical disclosure. Pennycook (2004: 795f.) is correct when he states that the agenda of applied linguistics must take this into account:

(12) ... critical applied linguistics might be viewed as an approach to language related questions that springs from an assumption that we live amid a world of pain. (Pennycook 2004: 797f)

After summarising the discussion once again in terms of an elaboration of the previous graphic, I return below to the future agenda for applied linguistics research:

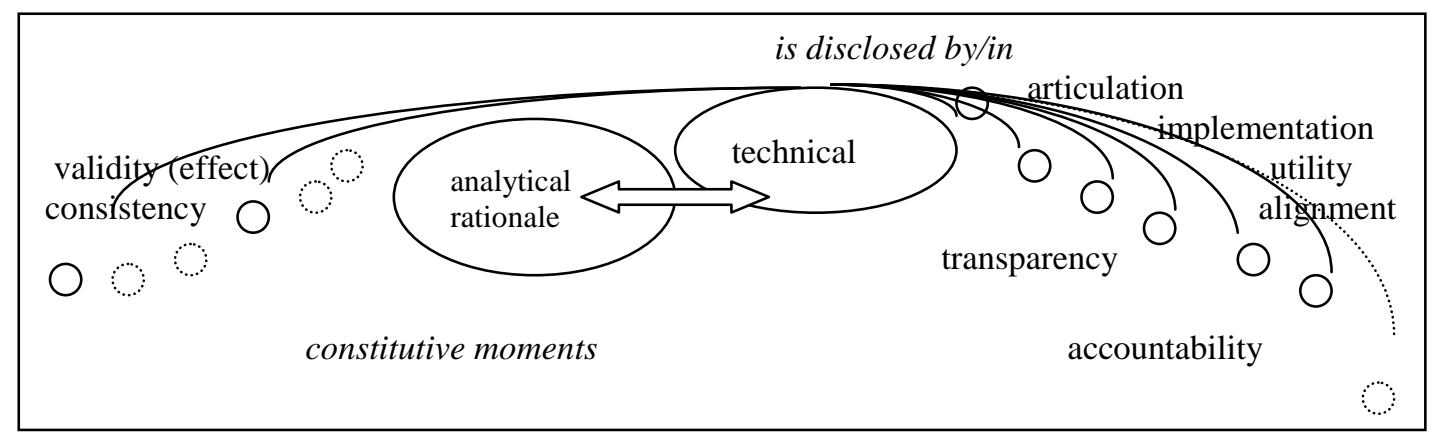

Figure 3: The disclosure of the leading technical function of an applied linguistic design 


\section{AN AGENDA SUGGESTED BY THE FRAMEWORK}

What is our agenda to be, as applied linguists, also for the times we are moving towards? My analysis here has articulated several, but I end by highlighting those that in my estimation most deserve our attention (cf. Weideman 1999). Deriving from the connections between the technical, qualifying aspect of its designs, and the analytical, juridical, aesthetic, economic, and ethical aspects of experience, some of the regulative conditions for applied linguistics, in this analysis, are that it should

\section{- counter all efforts to make teachers the victims of theory or of imposed designs}

Flowing from the relation between the technical dimension and the analytical and juridical, we should acknowledge that the argument for respecting the unique professional competence of teachers is too compelling to ignore. But we should be wary not merely to be exchanging old ideologies (to be 'scientific') for new ones (to be 'political').

\section{- work on designs that are more, not less imaginative}

We should not let technical restrictions or our own unfounded prejudices hold us back. Designs cannot function if they are not creative and forward looking. A short example: when we began to base our testing of academic literacy on a new, richer construct, there were many who doubted whether we could test that construct with multiple choice items. I believe we have demonstrated (Van der Slik \& Weideman 2005; Weideman \& Van Dyk 2004a, 2004b; Weideman \& Van der Slik 2007; Van der Slik \& Weideman 2007) now that we can test things like idiom, metaphor, text cohesion, genre sensitivity, and a whole host of other components of academic language imaginatively and creatively in that format. In theoretical framework terms: we should take the connection between the technical and aesthetic dimensions of applied linguistic work seriously.

\section{- emancipate teachers and users of our designs from toil and drudgery}

As designers of products that will be used by teachers and learners, we should never forget that our responsibility is to free them to do more creative things in the limited time that they have, in the case of students, to develop their language, and, in the case of teachers, to facilitate that development. If we can achieve that with new technologies, we should judiciously embrace those. We forget or underplay issues that concern the technical utility of our designs too easily, as if they are somewhat less important.

\section{- liberate language teachers and language professionals to works of care, service and mercy}

This point on our agenda reminds us that our designs are done because we demonstrate through them the love we have for others: it derives from the relation between the technical artefact that is our design and the ethical dimension of our life. In a country such as ours, satisfying the desperate language needs of both adults and children to achieve a functional literacy that will enable them to function in the economy and partake more fully of its fruits, stands out as possibly the biggest responsibility of applied linguists. Again, postmodernist perspectives have re-alerted us to the organisational and political 
impediments to achieve this, not the least of which is achieving literacy in one's first language.

Let me conclude this confession by noting that the philosophical framework that underlies my work has, in my view, given it some consistency over the years. The following statement (Weideman 1999: 95) continues to sum up my beliefs about where applied linguistics should go:

I take a view of applied linguistics that makes it embody an emancipatory, liberating and healing enterprise. The tasks ... for a redefined applied linguistics should also make it clear that in this idea of the discipline we are liberated not only from trends and dogmas, but to positive action.

As one reviewer has correctly remarked, the philosophical framework that lies behind this derives from Dooyeweerd's (1953) New critique of theoretical thought, although I relied more heavily in this instance on Schuurman's $(1972,2005)$ elaboration and reworking of these ideas for the technical sciences. As a philosopher and applied linguist, this is the framework that continues to influence my work.

\section{REFERENCES}

ALDERSON, JC, C CLAPHAM \& D WALL. 1995. Language test construction and evaluation. Cambridge: Cambridge University Press.

ALLEN, SPB \& SP CORDER (Eds). 1974. Techniques in applied linguistics. Volume 3 of The Edinburgh course in applied linguistics. Oxford: Oxford University Press.

ALLWRIGHT, D. 2006. Six promising directions in applied linguistics. In Gieve, S \& IK Miller (Eds), Understanding the language classroom. Basingstoke: Palgrave Macmillan.11-17.

BELL, DM 2003. Method and postmethod: Are they really so incompatible? TESOL Quarterly, 37 (2): 325-336.

BROWN, JD. 2004. Research methods for applied linguistics: Scope, characteristics and standards. In Davies, A \& C Elder (Eds), The handbook of applied linguistics. Oxford: Blackwell. 476-499.

BRUTHIAUX, P, D ATKINSON, WG EGGINGTON, W GRABE \& V RAMATHAN (Eds), Directions in applied linguistics: Essays in honor of Robert B. Kaplan. Clevedon: Multilingual Matters.

BUCKINGHAM, T \& DE ESKEY. 1980. Toward a redefinition of applied linguistics. In Kaplan, RB (Ed.), The Oxford handbook of applied linguistics. Oxford: Oxford University Press. 1-3.

BYGATE, M. 2004. Some current trends in applied linguistics. Towards a generic view. AILA Review, 17:6-22. 
CARROLL, JB. 1965. The contributions of psychological theory and educational research to the teaching of foreign languages. Reprinted from The Modern Language Journal, 49: 273-281 in Smolinski, F (Ed) Landmarks of American language \& linguistics. Washington: United States Information Agency. 203-211.

COPE, B \& M KALANTZIS (Eds). 2000. Multiliteracies: Literacy learning and the design of social futures. London: Routledge.

COPE, B \& M KALANTZIS. 2000a. Introduction. Multiliteracies: The beginnings of an idea. In Cope, B \& M Kalantzis (Eds), Multiliteracies: Literacy learning and the design of social futures. London: Routledge. 3-8.

COPE, B \& M KALANTZIS. 2000b. Designs for social futures. In Cope, B \& M Kalantzis (Eds), Multiliteracies: Literacy learning and the design of social futures. London: Routledge. 203-234.

CORDER, SP. 1972. Problems and solutions in applied linguistics. In Qvistgaard, J, H Schwarz \& H Spang-Hanssen (Eds) 1972: 1-23. Applied linguistics: Problems and solutions. Vol. III of the Association Internationale de Linguistique Applique Third Congress, Copenhagen. Heidelberg: Julius Groos Verlag.

DAVIES, A. 1999. An introduction to applied linguistics: From practice to theory. Edinburgh: Edinburgh University Press.

DAVIES, A \& C ELDER (Eds). 2004. The handbook of applied linguistics. Oxford: Blackwell.

DAVIES, A \& HG WIDDOWSON. 1974. Reading and writing. In Allen, JPB \& SP Corder 1974: 155-201.

DOOYWEERD, H. 1953. A new critique of theoretical thought. 4 volumes. Amsterdam: H.J. Paris.

DOUGHTY, C \& T PICA. 1986. 'Information gap' tasks: Do they facilitate second language acquisition? TESOL Quarterly, 20 (2): 305-325.

FOSTER, P. 1998. A classroom perspective on the negotiation of meaning. Applied Linguistics, 19 (1): 1-23.

GIEVE, S \& IK MILLER (Eds). 2006. Understanding the language classroom. Basingstoke: Palgrave Macmillan.

GREYLING, WJ. 1993. Making predictions about learner experiences: Applied linguistics and decision-making in the classroom. South African Journal of Linguistics, Supplement 18 (189-203).

HALLIDAY, MAK. 1978. Language as social semiotic. London: Edward Arnold.

HYMES, DH. 1971. On communicative competence. In Pride, JB \& J Holmes (Eds) 1972: 269-293. Sociolinguistics: Selected readings. Harmondsworth: Penguin.

HYMES, DH. 1985. Towards linguistic competence. AILA review, 2: 9-23. 
IVANIC, R. 2004. Discourses of writing and learning to write. Language and Education, 18 (3): 220-245.

JAKOBOVITS, LA \& B GORDON. 1974. The context of foreign language teaching. Rowley, Massachusetts: Newbury House.

JANKS, H. 2000. Domination, access, diversity and design: A synthesis for critical literacy education. Educational Review, 52 (2): 175-186.

JOHNS, AM. 2005a. Research and theory in the teaching of second/foreign language writing: Implications for pedagogy. MS. Paper read at SAALA $200525^{\text {th }}$ anniversary conference, Dikhololo, 6-8 July.

JOHNS, AM. 2005b. Personal communication.

KARAVAS-DOUKAS, E. 1996. Using attitude scales to investigate teachers' attitudes to the communicative approach. In ELT Journal, 50 (3): 187-198.

KAPLAN, RB. 1980a. Toward a redefinition of applied linguistics. In Kaplan, RB (Ed.), The Oxford handbook of applied linguistics. Oxford: Oxford University Press. 9-12.

KAPLAN, RB. 1980b. On the scope of linguistics, applied and non-. In Kaplan, RB (Ed) The Oxford handbook of applied linguistics. Oxford: Oxford University Press. 57-66.

KAPLAN, RB (Ed). 1980. On the scope of applied linguistics. Rowley, Massachusetts: Newbury House.

KAPLAN, RB (Ed). 2002. The Oxford handbook of applied linguistics. Oxford: Oxford University Press.

KLOSEK, J. 1985. Applied linguistics - free at last. TESOL Applied Linguistics Interest Section Newsletter, 6 (1): 14-15.

KRASHEN, SD \& TD TERRELL. 1983. The natural approach: Language acquisition in the classroom. Oxford / San Francisco: Pergamon / Alemany.

KUMARAVADIVELU, B. 2003. Beyond methods: Macrostrategies for language teaching. London: Yale University Press.

KUMARAVADIVELU, B. 2006. Applied linguistics in the age of globalization. Translated and published in Portuguese as 'A linguistica aplicada na era da globalizacao.' In Moita Lopes, LP (Ed) 2006: 129-148. New ways of doing applied linguistics / Por uma linguistica aplicada indisciplinar: Sao Paulo, Brazil: Parabola Editorial.

LADO, R. 1964. Language teaching: A scientific approach. New York: McGraw-Hill.

LAMENDELLA, JT. 1979. The neurofunctional basis of pattern practice. TESOL Quarterly, 13 (1): 5-19. 
LARSEN-FREEMAN, D. 1986. Techniques and principles in language teaching. New York: Oxford University Press.

LARSEN-FREEMAN, D. 1993. Foreign language teaching methodology and teacher education. Keynote address at AILA conference, Amsterdam.

LEKI, I. 2002. Second language writing. In Kaplan, RB (Ed.), The Oxford handbook of applied linguistics. Oxford: Oxford University Press. 60-69.

LIGHTBOWN, PM, \& N SPADA. 1993. How languages are learned. Oxford: Oxford University Press.

LILLIS, T. 2003. Student writing as 'academic literacies': Drawing on Bakhtin to move from critique to design. Language and Education, 17 (3):192-207.

MACDONALD, C. 1988. Teaching primary science in a second language: two teaching styles and their cognitive concomitants. In Weideman, AJ (Ed) Styles of teaching and styles of learning. Proceedings of the 6th Southern African Applied Linguistics Association conference.115-127.

MACDONALD, C \& E BURROUGHS. 1991. Eager to talk and learn and think: Bilingual primary education in South Africa. Cape Town : Maskew Miller Longman.

MESSICK, S. 1988. The once and future issues of validity: Assessing the meaning and consequences of measurement. In Warner, H \& IH Braun (Eds) 1988: 33-45. Test validity. New Jersey: Lawrence Erlbaum Associates.

MOULTON, J. 1994. Interactive radio instruction: Broadening the definition. s.1.: LearnTech.

MUNBY, J. 1978. Communicative syllabus design. Cambridge: Cambridge University Press.

NEW LONDON GROUP, THE. 2000. A pedagogy of multiliteracies. In Cope, B \& M Kalantzis (Eds), Multiliteracies: Literacy learning and the design of social futures. London: Routledge. 9-37.

NEWMARK, L. 1966. How not to interfere with language learning. Reprinted from the International Journal of American Linguistics, 32 (1\& 2) in Brumfit, CJ \& K Johnson (Eds) 1979, The communicative approach to language teaching. Oxford: Oxford University Press. 160-166.

NUNAN, D. 1991. Communicative tasks and the language curriculum. TESOL Quarterly, 25 (2):279-295.

OLIVER, R. 2000. Age difference in negotiation and feedback in classroom and pair work. Language Learning, 50 (1):119-151.

PAULSTON, CB. 1974. Linguistic and communicative competence. TESOL Quarterly, 8 (4): 347-362. 
PENNYCOOK, A. 1999. Introduction: Critical approaches to TESOL. TESOL Quarterly, 33 (3):329-347.

PENNYCOOK. A. 2000. The social politics and the cultural politics of language classrooms. In Hall, JK \& WG Eggington (Eds) 2000: 89-103. The sociopolitics of English language teaching. Clevedon: Multilingual Matters.

PENNYCOOK, A. 2004. Critical applied linguistics. In Davies, A \& C Elder (Eds), The handbook of applied linguistics. Oxford: Blackwell. 784-807.

PICA, T. 1987. Second language acquisition, social interaction, and the classroom. Applied Linguistics, 8 (1): 3-21.

PICA, T. 1994. Research on negotiation: What does it reveal about second language learning conditions, processes, and outcomes? Language Learning, 44 (3): 493-527.

PICA, T. 1996. Do second language learners need negotiation? International Review of Applied Linguistics, 34 (1): 1-21.

PICA, T \& C DOUGHTY. 1985. Input and interaction in the communicative language classroom: A comparison of teacher-fronted and group activities. In Gass, SM \& C Madden (Eds) 1985: 115-132. Input in second language acquisition. Cambridge, Massachusetts: Newbury House.

PICA, T, L HOLLIDAY, N LEWIS \& L MORGENTHALER. 1989. Comprehensible output as an outcome of linguistic demands on the learner. Studies in Second Language Acquisition, 11: 63-90.

PICA, T, R KANAGY \& J FALODUN. 1993. Choosing and using communication tasks for second language instruction. In Crookes, G \& SM Gass (Eds) 1993: 9-34. Tasks and language learning: integrating theory and practice. Clevedon: Multilingual Matters.

PICA, T, R YOUNG. \& C DOUGHTY. 1987. The impact of interaction on comprehension. TESOL Quarterly, 21 (4): 737-758.

PORTER, PA. 1986. How learners talk to each other: Input and interaction in task-centred discussions. In Day, RR (Ed) 1986: 200-222. Talking to learn: conversation in second language acquisition. Rowley, Massachusetts: Newbury House.

PRATOR, C. 1965. Development of a manipulation-communication scale. Reprinted from NAFSA Studies and Papers, English Language Series, 10: 385-391 in Smolinski, F (Ed.) 1985, Landmarks of American language \& linguistics. Washington: United States Information Agency. 248-252.

RAJAGOPALAN, K. 2004. The philosophy of applied linguistics. In Davies, A \& C Elder (Eds), The handbook of applied linguistics. Oxford: Blackwell. 397-420.

SCHUURMAN, E. 1972. Techniek en toekomst: Confrontatie met wijsgerige beschouwingen. Assen: Van Gorcum. 
SCHUURMAN, E. 1977. Reflections on the technological society. Jordan Station, Ontario: Wedge Publishing Foundation.

SCHUURMAN, E. 2005. The technological world picture and an ethics of responsibility: Struggles in the ethics of technology. Sioux Center, Iowa: Dordt College Press.

SHAALUKENI, L. 2000. Learner-centredness and group work in second language teaching: A shattered dream. The case of five primary schools in the Ondangwa West region, Namibia. Unpublished Master's mini-thesis. Bellville: University of the Western Cape.

SMOLINSKI, F (Ed). 1985. Landmarks of American language \& linguistics. Washington: United States Information Agency.

SPOLSKY, B. 2005. Is language policy applied linguistics? In Bruthiaux. P, D Atkinson, WG Eggington, W Grabe \& V Ramathan (Eds) Directions in applied linguistics: Essays in honor of Robert B. Kaplan. Clevedon: Multilingual Matters. 26-36.

TARONE, EE. 2005. Language lessons: A complex, local co-production of all participants. In Gieve, S \& IK Miller (Eds), Understanding the language classroom. Basingstoke:Palgrave Macmillan.163-174.

TERRELL, TD. 1985. The Natural Approach to language teaching: An update. Canadian Modern Language Review, 41 (3):461-479.

TESFAMARIAM, H. 2000. The alignment of the Grade 8 English syllabus in Eritrea with its implementation in the classroom. Bellville: University of the Western Cape. Unpublished Master's mini-thesis.

VAN DER SLIK, F \& AJ WEIDEMAN. 2005. The refinement of a test of academic literacy. Per Linguam, 21 (1):23-35.

VAN DER SLIK, F \& AJ WEIDEMAN. 2007. Measures of improvement in academic literacy. Submitted to Southern African Linguistics and Applied Language Studies.

VAN RIESSEN, H. 1949. Filosofie en techniek. Kampen: Kok.

VARONIS, EM \& S GASS. 1985. Non-native/non-native conversations: A model for negotiation of meaning. Applied Linguistics, 6 (1):71-90.

WALZ, J. 1996. The classroom dynamics of information gap activities. Foreign Language Annals, 29 (3):481-494.

WEIDEMAN, AJ. 1983. The systematic bases for the distinction linguistics/applied linguistics. SA Journal of Linguistics, 1 (1):38-52.

WEIDEMAN, AJ. 1985. Vier rigtings in kommunikatiewe taalonderrig. Neon, 48: 42-51.

WEIDEMAN, AJ. 1986. Directions in communicative language teaching. L.A.U.D.T. Papers, B150. $21 \mathrm{pp}$. 
WEIDEMAN, AJ. 1987. Applied linguistics as a discipline of design: A foundational study. Unpublished doctoral thesis, University of the Free State.

WEIDEMAN, AJ. (Ed). 1988. Styles of teaching and styles of learning. Proceedings of the 6th Southern African Applied Linguistics Association conference. Bloemfontein: University of the Orange Free State.

WEIDEMAN, AJ. (Ed). 1994. Redefining applied linguistics. Proceedings of the $14^{\text {th }}$ annual conference of the Southern African Applied Linguistics Association. Bloemfontein: SAALA.

WEIDEMAN, AJ. 1999. Five generations of applied linguistics: Some framework issues. Acta Academica, 31 (1):77-98.

WEIDEMAN, AJ. 2000. (Ed) Socially responsible applied linguistics. Proceedings of the Southern African Applied Linguistics Association 2000 conference. Vols 1 \& 2. Bellville: SAALA.

WEIDEMAN, AJ. 2001. The old and the new: Reconsidering eclecticism in language teaching. Per Linguam, 17 (1):1-13.

WEIDEMAN, AJ. 2002a. Designing language teaching: On becoming a reflective professional. Pretoria: BE at UP.

WEIDEMAN, AJ. 2002b. Overcoming resistance to innovation: suggestions for encouraging change in language teaching. Per Linguam, 18(1):27-40.

WEIDEMAN, AJ. 2003. Towards accountability: A point of orientation for post-modern applied linguistics in the third millennium. Literator, 24 (1):1-20.

WEIDEMAN, AJ. 2006a. Transparency and accountability in applied linguistics. Southern African Linguistics and Applied Language Studies, 24 (1):71-86.

WEIDEMAN, AJ. 2006b. A systematically significant episode in applied linguistics. In Lategan, LOK \& JH Smit (Guest eds) 2006: 231-244. Time and context relevant philosophy. Special edition 1 of the Journal for Christian Scholarship, 42.

WEIDEMAN, AJ. 2007a. Overlapping and divergent agendas: Writing and applied linguistics research. In Van der Walt, C (Ed). 2007: 147-163. Living through languages: An African tribute to Rene Dirven. Stellenbosch: African Sun Media.

WEIDEMAN, AJ. 2007b. The redefinition of applied linguistics: Modernist and postmodernist views. Forthcoming in Southern African Linguistics and Applied Language Studies, 25(4).

WEIDEMAN, AJ. 2007c. Academic literacy: Prepare to learn. Second edition. Pretoria: Van Schaik. 
WEIDEMAN, AJ, H TESFAMARIAM \& L SHAALUKENI. 2003. Resistance to change in language teaching: Some African case studies. Southern African Linguistics and Applied Language Studies, 21 (1 \& 2):67-76.

WEIDEMAN, AJ. \& F VAN DER SLIK. 2007. The stability of test design: Measuring difference in performance across several administrations of a test of academic literacy. Forthcoming in Acta Academica.

WEIDEMAN, AJ. \& T VAN DYK, T. 2004a. Switching constructs: On the selection of an appropriate blueprint for academic literacy assessment. SAALT Journal for Language Teaching, 38 (1):1-13.

WEIDEMAN, AJ. \& T VAN DYK. 2004b. Finding the right measure: From blueprint to specification to item type. SAALT Journal for Language Teaching, 38 (1): 15-24.

WIDDOWSON, HG. 2005. Applied linguistics, interdisciplinarity, and disparate realities. In Bruthiaux. P, D Atkinson, WG Eggington, W Grabe \& V Ramathan (Eds) 2005: 1225 .

WILKINS, DA. 1975. Linguistics in language teaching. London: Edward Arnold.

WILKINS, DA. 1976. Notional syllabuses: A taxonomy and its relevance to foreign language curriculum development. Oxford: Oxford University Press.

YOUNG, D. 2005. After 25 years, is SAALA making a difference to our research, understanding, teaching and language praxis in our multilingual society? Opening keynote address: SAALA/LSSA Conference, Dikhololo, 7 July 2005. In Geldenhuys, J \& B Lepota (Eds). Proceedings of the joint SAALA/LSSA 2005 conference. Pretoria: SAALA. 37-65.

\section{BIOGRAPHIC NOTE}

Albert Weideman is director of the Unit for Academic Literacy of the University of Pretoria. His main interest is in language testing, but he is also the author of the Academic literacy: prepare to learn, now in its second (2007) printing. E-mail: albert.weideman@up.ac.za 